\title{
KRÓTKI ZARYS EWOLUCJI FILOLOGII: UJĘCIE 'PORTALOWE'
}

\author{
STANISŁAW PUPPEL
}

\begin{abstract}
In the paper, the author postulates that philology may be characterized by an evolutionary sequence: from classical philology, to modern native and nonnative types of philologies, to the expected panphilology. The portals perspective applied in the paper has allowed the author to investigate all four evolutionary phases with special emphasis on the latest phase of the proposed evolutionary sequence. Panphilology has been described in greater detail as characterized by such features as an open and eclectic type of studies, cosmopolitanism and students' freedom in selecting their highly individual paths of studies.
\end{abstract}

Key words: evolution of philology, classical philology, modern native philology, modern nonnative philology, panphilology, the portals perspective, philological scale, global cultural-linguisticcommunicative space

Wsystkim, którzy przyczynili się
i nadal przyczyniaja się do
ewolucji filologii, pracę tę
dedykuje
autor

\section{Wstęp}

Fascynacja zjawiskiem języka od zawsze towarzyszyła ludzkości. Nie dziwi więc, że 'filologia' (F, jako zbitka greckich słów 'philos' (umiłowanie) i 'logos' (słowo) na określenie 'umiłowania słowa, języka') powstała jako jeden z najwcześniejszych jeśli nie najwcześniejszy nurt w rozwoju namysłu nad człowiekiem jako komunikatorem jak i myśli naukowej w organicznym połączeniu z silnym nurtem 
'zawodowym', czyli stosowanym. Zakłada się, że od samego więc początku swojego autonomicznego istnienia $\mathrm{w}$ łonie nauki filologia zawarła $\mathrm{w}$ sobie ścisły dualizm teorii (refleksji nad słowem jako podmiotowym wyznacznikiem filologii wraz z jego historią) i praktyki dotyczącej słowa i różnych technologii jego stosowania w przestrzeni publicznej (zob. Peile, 1877). Zakłada się także, że w chwili obecnej F zawiera w sobie cztery fazy ewolucyjne (I-IV), wykształcone w okresie w przybliżeniu dwóch i pół mileniów swojego istnienia. Są to:

- Filologia klasyczna (FK)

- Filologia nowożytna rodzima (FNR)

- Filologia nowożytna nierodzima (FNN, zwana także 'neofilologią')

- Panfilologia (PF).

Fazy te ilustruje poniższy schemat (Rys. 1):

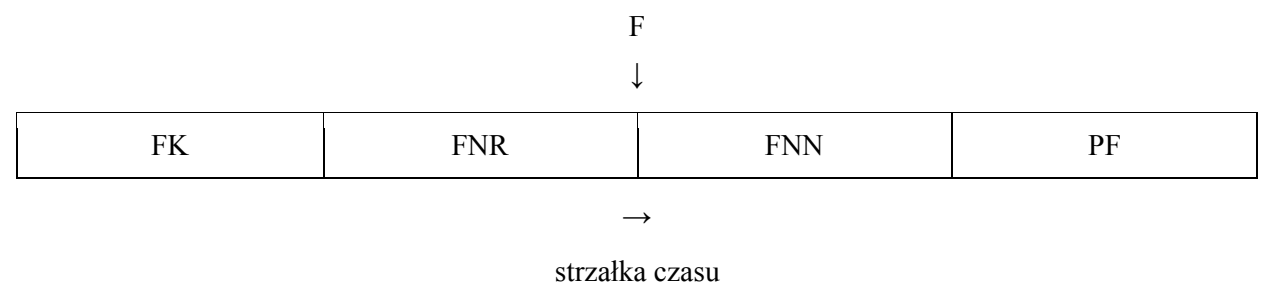

Rys. 1. Sekwencja ewolucyjna filologii (F)

Trzy pierwsze fazy ewolucji filologii, tj. FK, FNR i FNN, są jednoznaczne i mają charakter zdecydowanie dualny, teoretyczno-stosowany (tj. ściśle zawodowy, praktyczny), natomiast faza PF, będąca fazą najnowszą i stopniowo ujawniającą się, z pewnością rozwijać się będzie bardziej trójczłonowo. Zakłada się, że zawierać będzie ona $\mathrm{w}$ sobie zarówno kształcenie w ramach tradycyjnego dualizmu komponentów: (1) teorii i (2) poszerzonej praktyki zawodowej oraz dodanej do nich (3) coraz wyraźniejszej i coraz bardziej rozbudowanej części niejako 'poza zawodowej', związanej głównie z osobistym rozwojem danego uczestnika edukacji filologicznej, mającej miejsce w obliczu chociażby wyraźnie prognozowanych zmian w strukturze zawodowej współczesnego człowieka. Tak więc wydaje się, że rozwój ten nie będzie związany ściśle z koniecznym zdobywaniem jakiegoś zawodu związanego z użyciem językowym i programowo oparty będzie na założonej maksymalnej otwartości na wszystkie języki naturalne wchodzące w skład 'globalnej areny języków naturalnych' i zawierające je kultury lokalne (zob. bibliografia), zarówno w technologicznie coraz bardziej zaawansowanym porządku komunikacyjnym graficznym (pisanym i drukowanym) jak i w pierwotnym porządku ustnym (mówionym). Zatem zakłada się, że faza najnowsza ewolucji $\mathrm{F}$ będzie obejmować dwie części: dwukomponentową część zawodową (z teorią i praktyką) oraz część 
poza zawodową. Słowem, uczestnik tych studiów otrzymywać będzie programowo coraz bardziej globalną perspektywę w zakresie języków naturalnych i obejmujących je kultur lokalnych. Poniżej omówione zostaną wszystkie cztery fazy ewolucyjne F (I-IV).

\section{Filologia klasyczna (FK)}

Tę część opracowania otwiera lista wybitnych (wybranych) przedstawicieli okresu klasycznego, którzy swoją twórczością stworzyli podwaliny pod F i FK i w zasadzie nadali impet dalszemu rozwojowi F. Lista ta może wyglądać następująco: Homer (VIII wiek p.n.e.), Hezjod (Hesiodos z Beocji, VIII/VII wiek p.n.e.),

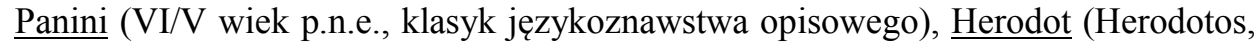
484 p.n.e. -426 p.n.e.), Warro (Marcus Terentius Varro, 116 p.n.e. -27 p.n.e., wybitny filolog klasyczny, klasyk językoznawstwa opisowego), Platon (427 p.n.e. 347 p.n.e., pierwszy użył terminu 'philologos' w dziele Theatetus 146 A na oznaczenie 'miłośnika dyskusji naukowej'), Arystoteles (348 p.n.e. - 322 p.n.e., ojciec retoryki klasycznej), Cyceron (Marcus Tullius Cicero, 106 p.n.e. - 43 p.n.e., uważany za jednego z ojców retoryki klasycznej w okresie rzymskim), Owidiusz (Publius Ovidius Naso, 43 p.n.e. $-17 / 18$ n.e.), Wergiliusz (Publius Vergilius Maro, 70 p.n.e. -19 p.n.e.)

Niezwykle ważna dla rozwoju F jest faza rozwoju 'filologii klasycznej' (FK), z pewnością wyprowadzona z wcześniejszej i przedhistorycznej fazy 'przedfilologicznej', która w Europie związana jest od początku istnienia FK ze ściśle 'punktową' (tj. ograniczoną do wybranego języka klasycznego (status języka względem innych języków: monoglossia) i lokalnej kultury go otaczającej (status kultury względem innych kultur: monocultura) analizą klasycznych (i martwych) języków naturalnych (głównie greki i łaciny), które jako podstawowy warunek zaistnienia tejże analizy osiągnęły przede wszystkim status języków w pełni wykształconych i funkcjonujących w 'porządku komunikacyjnym graficznym' (tj. pisanym, ang. literacy, obok, oczywiście, prymarnego dla wszystkich języków naturalnych bez wyjątku 'porządku komunikacyjnego ustnego', zob. np. Ong, 1982; Goody, 1987; Graff i Warner, 1989; Harris, 1991), w ramach trivium obejmującego gramatykę, logikę (dialektykę) i retorykę (zob. John of Salisbury, 2009).

Analiza ta od początku istnienia FK prowadzona jest według ostatecznie wypracowanego w tej fazie następującego schematu - zwanego tutaj 'układem filologicznym klasycznym' (UFK, ang. classical philological design) - tj. z punktu widzenia obowiązkowej analizy synergicznego współdziałania następujących po sobie linearnie ułożonych komponentów tego układu, realizowanych w silnie nieautonomicznym i zakładającym stosowanie nauczycielskiej przemocy wobec uczniów/studentów systemie ‘dydaktyki paternalistycznej' (zob. np. Freire, 1970/2005; Downey 
i Kelly, 1979; Skowronek, 2009; Puppel, 2012). Układ ten można całościowo określić jako układ oparty na pełnej 'synchronizacji filologicznej' następujących komponentów:

- wszelkiej spuścizny literackiej i pisemnej w obrębie danego języka klasycznego (WSLiPJK), tj. zasobów rozwiniętych w porządku komunikacyjnym graficznym, zawierającym wszelkie dzieła pisane $\mathrm{w}$ epoce klasycznej $\mathrm{w}$ formie traktatów historycznych, politycznych, filozoficznych, ekonomicznych, religijnych, dzieł literackich, poezji, etc., wraz z wszelkimi pisanymi komentarzami krytyczno-literackimi rozwijanymi w okresie poklasycznym i nowożytnym

- analizy strukturalnej danego języka klasycznego (ASJK), tj. analizy struktury języka naturalnego zawartego w WSLiPJK w poszczególnych językach klasycznych, a więc 'kawałkowania' danego języka na różnych poziomach jego struktury w podstawowe jednostki strukturalne z podaniem reguł ich wiązania, z uwzględnieniem historii danego języka naturalnego (zob. np. Panini; Peile, 1877; Dinneen, 1967)

- analizy fonii i wymowy danego języka klasycznego (AFiWJK), tj. prób praktycznego odtwarzania przybliżonej fonii wymarłych języków klasycznych dla prowadzenia przez adeptów FK właściwej 'ustnej ekspresji werbalnej' (zob. np. Allen, 1965)

- analizy stylistycznej danego języka klasycznego (ASTJK), tj. analizy obecnego we wszystkich tekstach WSLiPJK autorstwa pisarzy klasycznych całego bogactwa figur retorycznych, wzorców składniowych i frazeologicznych

- analizy dziedzictwa (wybranej) kultury klasycznej (ADKK), tj. analizy szeroko pojętego dziedzictwa wybranej kultury klasycznej (antycznej), w tym takich dziedzin jak: architektura, teatr, rzeźba, malarstwo, filozofia, religia, prawo (zob. np. Winniczuk, 1986; Bogucki, 2008)

- wszelkich zastosowań praktycznych danego języka klasycznego (WZPJK), tj. zastosowania np. stylistyki $\mathrm{w}$ retoryce publicznej pisanej i mówionej dotyczącej instytucji społeczno-polityczno-religijnych (ars poetriae), właściwych fonetycznie recytacji 'świętych tekstów', poezji mówionej, w przedstawieniach teatralnych, w sztuce wygłaszania przemówień (później zaś w sztuce wygłaszania kazań, ars praedicandi), w prowadzeniu przez adeptów FK działalności literackiej i kancelaryjnej (np. w sztuce prowadzenia korespondencji, ars dictaminis, zob. np. Murphy, 1974; Murphy, 1989).

Tak więc filologię klasyczną stanowi 'układ filologiczny klasyczny' (UFK) złożony z następujących komponentów: WSLiPJK, ASJK, AFiWJK, ASTJK, ADKK, WZPJK. Komponenty te, jak już powiedziano powyżej, rozumiane są jako funkcjonujące w pełni holistycznie i synergicznie. Stanowiły one od zawsze i nadal stanowią istotę filologii klasycznej prowadzonej dziś w wielu jeszcze centrach akademickich na świecie. 
Mówiąc wprost: aby stać się filologiem klasycznym uczestnik studiów z zakresu FK musiał (i nadal musi) przyswoić sobie pełną sekwencję jak i pełną zawartość poszczególnych elementów składowych UFK, wchodząc wszakże do UFK tylko od strony WSLiPJK jako głównego 'portalu' i czyniąc to w szkole pod okiem wytrawnych nauczycieli-filologów klasycznych. Dodać należy w tym miejscu, że w ujęciu 'portalowym', zaproponowanym w niniejszym opracowaniu, pojęcie 'portalu' rozumiane jest architektonicznie, a więc jako określające 'wejście do wnętrza jakiegoś gmachu' (w niniejszym ujęciu gmachem takim jest 'układ filologiczny', w sprawie portalu jako detalu architektonicznego zob. np. Szolginia, 1992; Ching, 1997).

Optymalnym wynikiem edukacji w wymiarze UFK było i jest nasycenie przestrzeni edukacyjnej i społecznej przez zawodowo wąską grupę specjalistów w zakresie FK, głównie literaturoznawców (badaczy WSLiPJK), językoznawców badających języki klasyczne, kulturoznawców (z możliwym nachyleniem etnologicznym, etnograficznym i filozoficznym) oraz licencjonowanych nauczycieli języków klasycznych.

Graficznie strukturę fazy FK zawartej w UFK można przedstawić w następujący sposób:

UFK

\begin{tabular}{|l|l|l|l|l|l|}
\hline WSLiPJK & ASJK & AFiWJK & ASTJK & ADKK & WZPJK \\
\hline
\end{tabular}

Rys. 2. Schemat linearnej struktury 'układu filologicznego klasycznego' (UFK) w fazie FK Gdzie: strzałka pozioma ' $\rightarrow$ ' oznacza wejście do WSLiPJK jako głównego 'portalu' UFK prowadzącego do dalszych jego części.

W tym miejscu, dla zilustrowania wielkiej dojrzałości naukowej i dbałości przedstawicieli filologów klasycznych w rozwijaniu komponentu ASJK, a więc W wyjaśnianiu strukturalnych właściwości danego języka klasycznego (tutaj Sanskrytu), podany zostaje jako uzupełnienie krótki fragment dzieła wybitnego przedstawiciela FK na gruncie pozaeuropejskim, Paniniego, w thumaczeniu na język angielski (zob. bibliografia). Fragment ten wskazuje na niezwykle rozwiniętą metakompetencję językoznawczą autora i niezwykle nowoczesne wręcz akcentowanie strukturalnych (tj. morfologiczno-semantyczno-składniowych) właściwości danego języka naturalnego (tutaj Sanskrytu) przez Paniniego, słusznie uważanego za ojca językoznawstwa opisowego:

51. The affix ङণष् is employed after a compound Nominal-stem in which a name denoting the means wherewith, is the first nember, and the second member is a word formed by the Participle w, when the sense is that of 'a small quantity'. 
Na podstawie przedstawionego powyżej i traktowanego tutaj jako fundament schematu UKF wyprowadzić można ogólny schemat 'układu filologicznego' (UF), który obowiązuje w fazach I-III ewolucji $\mathrm{F}$ i który oparty jest na zjawisku dobrze rozwiniętego 'komunikacyjnego porządku graficznego' (pisanego i drukowanego). Tym samym stanowi on rdzeń filologii (F). Ma on zatem następującą postać:

UF
$\downarrow$
\begin{tabular}{|c|c|c|c|c|c|}
\hline WSLiP & AS & AFiW & AST & ADK & WZP \\
\hline
\end{tabular}

Rys. 3. Schemat linearnej struktury ogólnego układu filologicznego (UF)

Gdzie: strzałka pozioma ' $\rightarrow$ ' oznacza wejście do WSLiP jako głównego 'portalu' UF prowadzącego do dalszych jego części.

\section{Filologia nowożytna rodzima (FNR)}

Niezwykle ważna dla rozwoju F faza rozwoju 'filologii nowożytnej rodzimej' (FNR), która nastąpiła przede wszystkim w Europie w oparciu o równie niezwykle ważną instytucję uniwersytetu (zob. np. Haskins, 1923), związana jest z wykształceniem się w okresie poklasycznym całego szeregu mniejszych lub większych i jednocześnie ważnych języków określonych tutaj jako 'nowożytne' (tj. naturalnych języków poklasycznej/nowożytnej Europy), które można także określić z punktu widzenia stopnia ich 'tężyzny', tj. określić jako mniej lub bardziej 'tęgie' (podstawowy termin to 'tężyzna języków naturalnych', ang. natural language robustness, zob. np. Puppel, 2017, odnośnie definicji tego terminu), takich jak chociażby: angielskiego, francuskiego, niemieckiego, włoskiego, hiszpańskiego, portugalskiego, czeskiego, polskiego, rosyjskiego i wielu innych (zob. Europeans and their languages, 2006), traktowanych jako języki 'rodzime' (zob. uwagi w sprawie dychotomii 'język rodzimy - język nierodzimy’ zawarte w sekcji IV poniżej).

Istotnym elementem tej fazy jest, tak jak w przypadku języków klasycznych, osiągnięcie przez języki nowożytne, o których mowa, statusu języków w pełni rozwiniętych, tj. funkcjonujących przede wszystkim w 'porządku komunikacyjnym graficznym', a więc w oparciu o dobrze rozwiniętą spuściznę literacką i pisemną (tj. w porządku głównie pisanym, a od połowy XV wieku również drukowanym, zob. np. Levine, 1991; Kapr i Martin, 1996; Butler, 2010).

Faza FNR jest związana - zwłaszcza od początku XX wieku - z także koniecznie punktową w sensie zdefiniowanym powyżej analizą pojedynczych języków nowożytnych rodzimych określanych jako 'tęgie' (status języka: monoglossia) według ustalonego dla filologii klasycznej UFK i zawartego w UF, tj. z punktu widzenia 
koniecznego współdziałania (czyli inaczej 'synchronizacji filologicznej'), następujących komponentów klasycznego UFK, tym razem zmodyfikowanego do fazy nowożytnej. Stąd możemy mówić o wyprowadzonym z UF 'układzie filologicznym nowożytnym rodzimym' (UFNR), który obejmuje współdziałanie następujących komponentów:

- wszelkiej spuścizny literackiej i pisemnej danego jezzyka nowożytnego rodzimego (WSLiPJNR), obejmującej całokształt tej spuścizny w danym języku nowożytnym rodzimym, włącznie $\mathrm{z}$ wszelkimi pisanymi komentarzami krytyczno-literackimi, także z elementami porównawczymi w odniesieniu do analizy spuścizny literackiej innych wspólnot kulturowych

- analizy strukturalnej danego języka nowożytnego rodzimego (ASJNR), tj. analizy wszystkich zasobów języka pisanego i mówionego, poszerzonej o komponent porównawczy, zwłaszcza w ramach określonej rodziny językowej, z której pochodzi dany język nowożytny rodzimy, a więc szczegółowej analizy struktury określonego języka naturalnego rodzimego zawartego w WSiPLJNR w poszczególnych językach nowożytnych, tj. 'kawałkowania' danego języka rodzimego na różnych poziomach jego struktury w podstawowe jednostki strukturalne $\mathrm{z}$ podaniem reguł ich wiązania, $\mathrm{z}$ obowiązkowym uwzględnieniem historii danego języka nowożytnego rodzimego (zob. np. Klemensiewicz, 1974; Rospond, 2005 dla języka polskiego; czy bardziej ogólnie Algeo, 2010)

- analizy fonii i wymowy danego języka nowożytnego rodzimego (AFiWJNR), w tym silnego (a może nawet bezwyjątkowego) propagowania praktycznej wymowy standardowej, tzw. 'hiperpoprawnej' (ang. hypercorrect), czyli z wyraźnym pominięciem w praktycznym stosowaniu różnych odmianek wymowy regionalnej i wymowy gwarowej (zob. np. Ellis, 1964; Wells, 1982; Jones et al., 2011) jako wydzielonego i autonomicznego komponentu fonicznego dla prowadzenia przez adeptów FNR poprawnej 'ustnej ekspresji werbalnej' w ramach porządku komunikacyjnego ustnego

- analizy stylistycznej danego języka nowożytnego rodzimego (ASTJNR), tj. analizy wszelkich figur stylistycznych obecnych w tekstach autorów i pisarzy, a więc we wszelkich tekstach stworzonych w określonym języku nowożytnym

- analizy dziedzictwa kultury nowożytnej rodzimej (ADKNR), tj. umieszczenia poszczególnych języków nowożytnych rodzimych w kontekście danej kultury rodzimej (lokalnej), a więc w kontekście całokształtu rodzimego dziedzictwa kulturowego, w którym zanurzony jest dany język naturalny nowożytny rodzimy

- wszelkich zastosowań praktycznych danego języka nowożytnego rodzimego (WZPJNR) w porównaniu z językami klasycznymi poszerzonych o wytworzone w międzyczasie i dopuszczone do analizy bogate i zróżnicowane wa- 
rianty specjalistyczne danego języka, zwłaszcza takie jak: dyskurs społeczny, polityczny, artystyczny, naukowy, technologiczny, ekonomiczny, medialny (publicystyczny), religijny, a także rozwijaną intensywnie zwłaszcza w drugiej połowie XX wieku i na początku XXI wieku 'glottodydaktykę języka rodzimego' (podawaną zarówno tradycyjnie jak i z zastosowaniem najnowszych nośników technologicznych w ramach zarówno dominującej 'dydaktyki paternalistycznej' jak i w ramach dydaktyki 'postpaternalistycznej', zob. np. Wobalis, 2017).

Tak więc FNR obejmuje zmodyfikowany UFNR z następującymi obowiązkowymi komponentami: WSLiPJNR, ASJNR (poszerzony o analizę w zakresie ważnego komponentu mówionego), AFiWJNR, ASTJNR, ADKNR, WZPJNR (znacząco poszerzony). Komponenty te stanowią istotę filologii nowożytnej rodzimej, także i tutaj programowo skupionej wyraźnie punktowo (tj. dyskretnie) na poszczególnych językach nowożytnych rodzimych, wymagających zawodowego przyswojenia i także, jak w przypadku FK, wymagających ich istnienia w pełni rozwiniętym porządku komunikacyjnym graficznym (pisanym i drukowanym).

Zauważyć należy w tym miejscu, że w wymiarze owego punktowego skupienia się na danym języku nowożytnym 'filologia nowożytna rodzima' może być z pewnością tożsama $\mathrm{z}$ 'filologią nowożytną nierodzimą' (tzw. 'neofilologią'), chociaż istotna różnica, jak to pokazano poniżej, polega na wprowadzeniu do układu filologicznego w wariancie nierodzimym, zwanego tutaj 'układem filologicznym nowożytnym nierodzimym' (UFNN), a więc w następnej fazie ewolucji, fazie tzw. 'neofilologii', niezwykle ważnej modyfikacji w postaci nowego i wręcz niezbywalnego komponentu w postaci analizy konfrontatywno-kontrastywnej między dwoma językami, rodzimym i nierodzimym, tj. na wprowadzeniu analizy o charakterze ściśle glottodydaktycznym (tj. stosowanym, zob. np. Zabrocki, 1975; Fisiak, 1991; Bańczerowski, 2001; odnośnie odpowiednich i nadal aktualnych ustaleń terminologicznych).

Mówiąc wprost: podobnie jak w przypadku filologa klasycznego, aby stać się filologiem nowożytnym rodzimym uczestnik studiów filologicznych nowożytnych rodzimych musiał (i nadal musi) przyswoić sobie zarówno pełną sekwencję jak i pełną zawartość poszczególnych elementów składowych UFNR, wchodząc wszakże do UFNR tylko od strony WSLiPJNR jako jedynego 'portalu' i zdobywając wąski profesjonalizm zawodowy oparty na zdecydowanie najważniejszym graficznym porządku komunikacyjnym (pisanym i drukowanym), czyniąc to ponadto w szkole pod okiem w pełni licencjonowanych nauczycieli filologów nowożytnych rodzimych.

Optymalnym wynikiem edukacji w wymiarze UFNR było i jest nasycenie przestrzeni edukacyjnej i społecznej przez zawodowo wąską grupę adeptów-specjalistów w zakresie FNR, głównie literaturoznawców (badaczy WSLiPJNR), językoznawców (w tym z nachyleniem stosowanym) i kulturoznawców ( $w$ tym z nachyleniem etnologicznym, etnograficznym i filozoficznym) badających dany JNR, nauczycieli języków nowożytnych rodzimych, także specjalistów w zakresie szeroko pojętych mediów. 
Graficznie strukturę fazy FNR zawartej w UFNR można przedstawić w następujący sposób:

UFNR

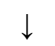

\begin{tabular}{|l|l|l|l|l|l|}
\hline WSLiPJNR & ASJNR & AFiWJNR & ASTJNR & ADKNR & WZPJNR \\
\hline
\end{tabular}

Rys. 4. Schemat linearnej struktury 'układu filologicznego nowożytnego rodzimego' (UFNR) w fazie FNR Gdzie: strzałka pozioma ' $\rightarrow$ ' oznacza wejście do WSLiPJNR jako głównego 'portalu' UFNR prowadzącego do dalszych jego części.

\section{Filologia nowożytna nierodzima (FNN, zwana także 'neofilologią')}

Szczyt rozwoju filologii nowożytnej nierodzimej (FNN) jako kolejnej fazy strukturalnie mocno związanej z FNR w sensie również ściśle punktowego skupienia się na określonym języku naturalnym nierodzimym przypadł $\mathrm{w}$ ewolucji $\mathrm{F}$ na drugą połowę XX wieku. Stąd też okres ten nazwać można okresem klasycznym w rozwoju FNN. Najogólniej rzecz biorąc, faza rozwoju FNN w Europie i w świecie związana była i nadal jest z wykształceniem się głównie po II Wojnie Światowej nad wyraz silnie praktycznej (a więc zawodowej) potrzeby uczenia się i nauczania ważnych (i jednocześnie 'tęgich') języków nowożytnych nierodzimych (tj. języków występujących w 'globalnej arenie języków naturalnych' nowożytnego świata, zob. np. Simons i Fennig, 2018) wedle ich miejsca na skali ich tężyzny i w konsekwencji na skali ich 'ważności' w przestrzeni kulturowo-edukacyjno-polityczno-ekonomicznej, takich jak chociażby: angielskiego, francuskiego, niemieckiego, włoskiego, hiszpańskiego, portugalskiego, czeskiego, polskiego, rosyjskiego i wielu innych (zob. np. Council of Europe, 2001; Europeans and their languages, 2006), z zachowaniem ich podstawowego statusu jako języków odpowiednio obficie rozwiniętych w dominującym 'porządku komunikacyjnym graficznym' (pisanym i drukowanym).

Stało się tak w obliczu postępującej zarówno jeszcze przedwojennej jak i powojennej intensyfikacji wymiany, a więc nieuniknionych kontaktów językowych, na wielu polach, w tym: militarnym, technologicznym, ekonomicznym, politycznym, kulturowo-artystycznym i naukowym, najpierw w przedwojennym i globalnym wymiarze Pax Britannica i swoistego Pax Romanica, a potem w powojennym i globalnym wymiarze Pax Americana (zob. np. Johnston, 2008).

Kontakty te wręcz wymuszały wprowadzenie problemu uczenia się i nauczania tzw. 'języków obcych' zwłaszcza w powojennej międzynarodowej przestrzeni edukacyjnej jako odrębnego nurtu $\mathrm{w}$ ewolucji F. Dotyczyło to (i nadal dotyczy) 
w szczególności języka angielskiego, który vis-a-vis innych języków naturalnych osiągnął wyjątkowo 'tęgi' charakter i niezwykle mocno globalizującą pozycję (angielski jako lingua globalis, zob. także Crystal, 2003).

Ogólnie rzecz biorąc, w tej fazie ewolucji $\mathrm{F}$ języki nowożytne są dodatkowo traktowane właśnie jako języki o globalnym wymiarze i jako 'obce' (określane w niniejszym opracowaniu jako 'nierodzime' $(\mathrm{JN})$, który to termin przyjmuje autor za bardziej właściwy, gdyż wydaje się być on zdecydowanie bardziej adekwatny, ze względu na jego mniejsze nacechowanie negatywne/ksenofobiczne) względem 'języków rodzimych' (JR), zob. także Puppel, 2000).

Języki określane mianem JN to takie, które przede wszystkim rozwinęły bogate zasoby w komunikacyjnym porządku graficznym i których dla różnych i przy tym zdecydowanie określonych celów zawodowych wynikających z intensywności kontaktów językowo-kulturowych trzeba się specjalnie uczyć według rygorystycznych programów nauczania, oraz których trzeba $\mathrm{w}$ związku $\mathrm{z}$ tym odrębnie nauczać w ramach niezwykle mocno rozbudowanego subkomponentu teoretyczno-praktycznego (stosowanego) o nazwie 'glottodydaktyka' (nb. zaproponowanego przez Ludwika Zabrockiego, m.in. w nazwie czasopisma Glottodidactica, założonego w 1966 roku w Poznaniu przez Zabrockiego, zob. np. Grucza, 2006; Skowronek, 2015).

Faza FNN jest fazą nadal intensywnie trwającą i rozwijaną w wielu ośrodkach neofilologicznych w Polsce, co jak już powiedziano powyżej, ma związek z niezwykle ważną społecznie praktyczną (zawodową) stroną współwystępowania języków nowożytnych w globalnej arenie języków naturalnych. Należy podkreślić, że faza FNN jest związana, zwłaszcza od początku $\mathrm{XX}$ wieku, $\mathrm{z}$ analizą, nauczaniem/uczeniem się języków nowożytnych nierodzimych głównie dla celów samopowielającego się mechanizmu utrzymywania zawodu nauczyciela języków nierodzimych (tj. kształcenia nauczycieli języków nierodzimych dla celów dalszego kształcenia i utrzymywania wysokiego stanu populacji nauczycieli języków nierodzimych, przy czym w Polsce stosuje się konsekwentnie termin 'nauczyciel języka obcego', zob. np. Marton, 1972; Skowronek, 2009; Komorowska, 2013; Dakowska, 2014). Czyni się to wedle następującego schematu, ustalonego już dla FK UFK, tj. z punktu widzenia koniecznego współdziałania następujących komponentów w obrębie zmodyfikowanego 'układu filologicznego nowożytnego nierodzimego' (UFNN):

- wszelkiej spuścizny literackiej i pisemnej w danym JNN (WSLiPJNN), tj. obejmującej całokształt tej spuścizny, wraz z wszelkimi pisanymi komentarzami krytyczno-literackimi, także z szeroko rozbudowanymi elementami porównawczymi w odniesieniu do spuścizny literackiej innych wspólnot kulturowych

- analizy strukturalnej danego JNN (ASJNN), tj. szczegółowej analizy rozwiniętych zasobów języka zarówno pisanego jak i mówionego, zdecydowanie poszerzonych o komponent porównawczo-konfrontatywno-kontrastywny da- 
nego JN vis-a-vis określonego JR, a więc 'kawałkowania' danego języka nowożytnego nierodzimego na różnych poziomach jego struktury w podstawowe jednostki strukturalne $\mathrm{z}$ podaniem reguł ich wiązania, $\mathrm{z}$ obowiązkowym uwzględnieniem historii danego języka nowożytnego nierodzimego

- analizy fonii i wymowy danego JNN (AFiWJNN) prowadzonej często w kontekście kontrastywnym, czyli w diadzie JN - JR, w tym silnego (a może nawet bezwyjątkowego) położenia nacisku na analizę i praktyczne uczenie (się) wymowy standardowej, tzw. 'hiperpoprawnej' (ang. hypercorrect), czyli z wyraźnym i celowym pominięciem w praktycznym stosowaniu różnych odmianek wymowy regionalnej i wymowy gwarowej danego języka nierodzimego, zatem analizy wydzielonego, autonomicznego i standardowego (tj. prestiżowego) komponentu fonicznego dla prowadzenia przez adeptów FNN poprawnej 'ustnej ekspresji werbalnej' w języku nowożytnym nierodzimym (zob. np. Gimson, 1962; Jassem, 1962, dla języka angielskiego) w ramach porządku komunikacyjnego ustnego

- analizy stylistycznej danego JNN (ASTJNN), a więc stylistyki i frazeologii obecnej we wszystkich tekstach spuścizny pisemnej i literackiej

- analizy dziedzictwa kultury nowożytnej nierodzimej (ADKNN), tj. umieszczenia poszczególnych języków nowożytnych nierodzimych w kontekście danej kultury lokalnej nierodzimej, a więc w kontekście całokształtu dziedzictwa kulturowego, w którym zanurzony jest dany język nowożytny nierodzimy, ale w uzupełniającym kontekście dziedzictwa kulturowego danego języka rodzimego

- wszelkich zastosowań praktycznych w wybranym JNN (WZPJNN) w porównaniu z językami klasycznymi szczególnie mocno poszerzonych o różne warianty specjalistyczne danego języka, zwłaszcza takie jak: dyskurs kulturowy, polityczny, technologiczny, ekonomiczny, naukowy i medialno-publicystyczny, w szczególności zaś poszerzonych o komponent glottodydaktyczny danego języka nowożytnego nierodzimego, nieustannie i intensywnie rozwijanego przez daną wspólnotę kulturowo-językowo-komunikacyjną w porządku zarówno mówionym jak i graficznym (pisanym/drukowanym), nauczanego zarówno w sposób tradycyjny jak i z zastosowaniem najnowszych nośników technologicznych, poszerzonych wreszcie o niezwykle rozbudowaną 'translatorykę’ jako szczególnie ważną część FNN, rozwiniętą zwłaszcza w okresie ostatniego ćwierćwiecza istnienia FNN (zob. bibliografia poniżej).

Tak więc istotę FNN stanowią, również jak w przypadku FNR skupionej punktowo na poszczególnych językach nowożytnych (nierodzimych), następujące komponenty: WSLiPJNN, ASJNN, AFiWJNN, ASTJNN, ADKNN, WZPJNN, tym razem koniecznie uzupełnione o podwójną perspektywę, a więc albo: (a) perspektywę dwujęzyczności (status języka: diglossia), zatem w tradycyjnie i szeroko stosowanych 'diadach filologicznych' (tj. obejmujących przede wszystkim klasyczną 
diadę: JN - JR, zob. np. Hui-chin Lin i Shih-chieh Chien, 2010; Celce-Murcia et al., 2014), lub/i (b) perspektywe trójiezzyczności, tj. bardziej nowocześnie w zdobywających coraz szersze uznanie i zastosowanie 'triadach filologicznych' (status języka: triglossia), a więc $\mathrm{w}$ triadach obejmujących $\mathrm{np}$. triadę: ważny międzynarodowo język nierodzimy - język rodzimy - inny język nierodzimy (np. język sąsiada) (zob. np. Hufeisen i Neuner, 2004; Puppel i Puppel, 2005; Wiśniewska, 2018).

Mówiąc wprost: podobnie jak w przypadku filologa klasycznego i filologa nowożytnego rodzimego, aby stać się filologiem nowożytnym nierodzimym (tj. 'neofilologiem') i zdobyć założony przez ten układ wąski profesjonalizm zawodowy (głównie nauczycielsko-translatoryczny) uczestnik studiów w zakresie filologii nowożytnych nierodzimych musiał (i nadal musi) przyswoić sobie pełną zawartość poszczególnych elementów składowych UFNN, wchodząc wszakże do UFNN wyłącznie od strony WSLiPJNN jako głównego 'portalu', zdobywając zatem wąski profesjonalizm zawodowy oparty zasadniczo na graficznym porządku komunikacyjnym (pisanym i drukowanym) i czyniąc to w szkole pod czujnym okiem w pełni licencjonowanych nauczycieli filologów nowożytnych nierodzimych, realizujących rygorystyczne programy nauczania przy centralnym dla tego układu założeniu, że uczenie się w obrębie tego układu jest wynikiem otrzymanego przez uczestników studiów odpowiedniego instruktażu.

Optymalnym wynikiem edukacji w wymiarze UFNN było i jest nasycenie przestrzeni edukacyjnej i społecznej przez zawodowo wąską grupę adeptów-specjalistów w zakresie FNN, głównie literaturoznawców (badaczy WSLiPJNN), językoznawców (w tym z nachyleniem stosowanym) i kulturoznawców (w tym z nachyleniem etnologicznym, etnograficznym, antropologicznym i filozoficznym, zob. np. McLeod, 1976; Damen, 1987; Saville-Troike, 1989; Kramsch, 1993; Kottak et al., 1997; Byram i Fleming, 1998; Appadurai, 1996; Scott i Huntington, 2000; Roberts et al., 2001; Harklau, 2005; Heath i Street, 2008) badających dany JN, nauczycieli języków nowożytnych nierodzimych, tłumaczy, także specjalistów w zakresie szeroko pojętych mediów i public relations (nb. klasycznym przykładem tak 'zbiorczo' prowadzonej edukacji może być publikacja Polska - Europa Wschodnia, 2017, zob. bibliografia).

Graficznie strukturę fazy FNN zawartej w 'układzie filologicznym nowożytnym nierodzimym’ (UFNN) można przedstawić w następujący sposób:

UFNN

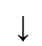

\begin{tabular}{|l|l|l|l|l|l|}
\hline WSLiPJNN & ASJNN & AFiWJNN & ASTJNN & ADKNN & WZPJNN \\
\hline
\end{tabular}

Rys. 5. Schemat linearnej struktury ‘układu filologicznego nowożytnego nierodzimego' (UFNN) w fazie FNN Gdzie: strzałka pozioma ' $\rightarrow$ ' oznacza wejście do WSLiPJNN jako głównego 'portalu' UFNN prowadzącego do dalszych jego części. 
W tym momencie, biorąc pod uwagę ustalony bardzo wcześnie w ewolucji $\mathrm{F}$ wspólny kształt powyżej opisanych układów filologicznych (UFK, UFNR, UFNN), można układy te nazwać ortodoksyjnymi w sensie długiego okresu ich trwania i niezmiennego stosowania. $\mathrm{W}$ tym względzie należy też $\mathrm{z}$ całą pewnością nie zapominać o tak ważnym dla rozwoju ortodoksji filologicznej w obrębie nowożytnej szkoły europejskiej jezuickim dokumencie programowym o nazwie Ratio studiorum (pełna nazwa tego dokumentu: Ratio atque Institutio Studiorum Societatis Iesu) z roku 1599, który na kilka stuleci ukształtował charakter zwłaszcza UFK i pośrednio UFN, w szczególności w części IV tego dokumentu, Studia inferiora, określającej jak należy nauczać w wymiarze właśnie filologicznym (zob. np. Górecki, 2014).

Tak więc fazy I-III ewolucji F stanowią filologiczną ( $\mathrm{tj}$. strukturalno-treściową) ortodoksję, w szczególności ortodoksję w wymiarze zawodowym. Nie można tego z całą pewnością powiedzieć o nowopowstającym układzie panfilologicznym opisanym poniżej.

\section{Panfilologia (PF)}

Jak już powiedziano na wstępie niniejszego opracowania, faza panfilologii (PF, czyli 'wszechfilologii') jest fazą najnowszą w ewolucji filologii. Jej pojawienie się i stopniowo zwiększana obecność na gruncie $\mathrm{F}$ związana jest $\mathrm{z}$ postępującym bardzo szybko procesem tworzenia się w globalnym wymiarze 'świata większej gęstości' bądź 'świata zwiększonej łączliwości' (ang. interconnected world) i, co się z tym ściśle wiąże, powstania naturalnej konieczności zdecydowanego poszerzenia międzyosobowych, międzyetnicznych i międzykulturowo-językowych kontaktów nie tylko w samym rdzeniu $\mathrm{F}$, tj. na gruncie ściśle zawodowym (a więc stosowanym/praktycznym: nauczycielskim/glottodydaktycznym i thumaczeniowym), który z pewnością będzie nadal przez jakiś czas utrzymany, lecz także w coraz bardziej rosnącym wymiarze swobodnych kontaktów (wielo)językowo-(wielo)kulturowych.

Jednocześnie założyć można, że proces kształtowania się PF następować będzie bez szczególnego nacisku na zdobycie konkretnego zawodu związanego z szeroko i ortodoksyjnie pojętą F (zob. uwagi powyżej). Tak więc można założyć, że faza PF strukturalnie zawierać będzie w sobie trzy poprzednie fazy ewolucji $\mathrm{F}$, opisane powyżej, ale że będzie też miała wymiar zupełnie nowy, 'panfilologiczny', o czym będzie mowa w dalszej części niniejszego eseju.

Ponieważ prognozuje się dla XXI wieku zdecydowanie mniejszy niż dotychczas nacisk na zdobywanie różnych zawodów związanych bezpośrednio $\mathrm{z}$ punktową (monolingwalną/dwulingwalną/trójlingwalną) znajomością poszczególnych języków nierodzimych w kontekście FNN (co wyraźnie sygnalizują poważnie zaawansowane rozważania nad przyszłością i wręcz zanikiem różnych dotychczas utrzymywanych 
i ściśle rozgraniczanych zawodów, w tym także zawodu nauczyciela, oraz towarzyszącym tej tendencji zanikiem różnych tradycyjnych kompetencji zawodowych w XXI wieku i nieuniknionym powstawaniem nowych kompetencji zawodowych, zob. np. Karoly, 2004; Silva, 2008; Frey i Osborne, 2013; Sullivan, 2001; Framework for 21st century learning, 2009; Anderson Koenig, 2011; The future of jobs, 2016), nasuwa się w sposób zupełnie naturalny przypuszczenie graniczące wręcz z pewnością odnośnie znacznie większej roli akademicko sterowanej samoedukacji (zob. istotne w tym kontekście hasło: all education is self education) w postępowaniu pojedynczego uczestnika studiów filologicznych celem uzyskiwania bardziej mieszanych (hybrydowych i 'renesansowych') umiejętności.

Rodzi to pewność, że będzie on coraz intensywniej poszukiwał kontaktów z F na forum akademickim nie tylko (i wyłącznie) na zasadzie zdobycia konkretnego zawodu zaopatrzonego w odpowiedni i tradycyjny zestaw kompetencji zawodowych (np. nauczyciela, thumacza, zawodowego komentatora zjawisk kulturowych, specjalisty od reklamy i wizerunku, etc.) lecz właśnie na zasadzie spędzania coraz bardziej wydłużającego się czasu wolnego w formule ciągłego uzupełniania wiedzy, swoistego filologiczno-kulturowego zbieractwa o nacechowaniu zdecydowanie dodatnim, w kontekście szerokiej diady poznawczej 'język - kultura' i bez natychmiastowego zastosowania nabytej wiedzy w konkretnych, w pełni licencjonowanych i społecznie zamawianych zachowaniach zawodowych, jak to ma (miało) miejsce we wcześniejszych fazach ewolucji $\mathrm{F}$.

Tak więc rozwijany od drugiej połowy XX wieku w edukacji zachodniej edukacyjny paradygmat 'edukacji ciągłej' (ang. continuing education, lifelong learning, zob. np. Council of Europe, 2001; Kautz et al., 2014; Wilson i Hayes, 2000; Schütze i Slowley, 2012; Lamb i in., 2017), bardziej dostosowanej do utrzymywania powodzenia zawodowego w ciągu całego życia, będzie zdobywał coraz szersze uznanie i coraz szersze zastosowanie praktyczne, rozbudowując się w sposób autonomiczny obok tradycyjnego (tj. ortodoksyjnego) i ściśle zawodowego dualizmu filologicznego zawartego w sekwencji układów filologicznych: UFK, UFNR, UFNN, o których była mowa powyżej i które w całości determinowały wcześniejsze fazy ewolucji $F$ i które uczestnik takich studiów realizował w odpowiednio wczesnym okresie swojego życia. W ten sposób ukształtuje się nowy układ filologiczny, który można wstępnie nazwać ‘układem panfilologicznym' (UPF, a nawet 'postfilologicznym'), zarówno treściowo, w odniesieniu do autonomii uczestników tego typu studiów (zob. np. Dworkin, 1988; także Peterson et al., 2010) jak i w odniesieniu do indywidualnie mocno rozciągniętego czasu ich realizacji.

Można zatem w tym miejscu pozwolić sobie wręcz na określenie tego typu studiów filologicznych jako w pełni autonomicznych i wieloportalowych 'studiów ekspozycyjno-kompozycyjnych' (ang. exposition-composition studies, a więc studiów typu Expo-Compo, Pick and Mix, lub studiów typu Air Bus, bądź studiów typu 'zrób to sam', Do it yourself, DIY/edupunk, zob. np. Spencer, 2005; Guzzetti et al., 
2010; Lowndes, 2016; Sancho-Gil i Rivera-Vargas, 2016). Podczas odbywania tychże ich uczestnicy będą samodzielnie otwierać wybrany przez siebie dowolny 'portal' (zob. Puppel, 2018) prowadzący do określonych fragmentów ekspozycji i będą korzystać $\mathrm{z}$ nich na zasadzie 'wolnego wybiegu', tj. korzystania z bardziej swobodnego i wyzwolonego od ortodoksyjnie rygorystycznego, powiedziałbym wręcz 'chudego' mocą swojej ortodoksyjnej struktury, programu nauczania. Będą tym samym korzystać z wolnego od przymusu i w ten sposób bardziej rozproszonego poszukiwania w formie 'zwiedzania ekspozycji' na miejscu (in situ) lub w przestrzeni wirtualnej poprzez spotkania ze złożonymi i różnorodnymi kompleksami językowo-kulturowymi (tj. poprzez zdecydowanie 'bogatszą' mozaikę swoistych cząstkowych 'pejzaży etnicznych' składających się na globalny pejzaż etniczny, a więc swoistą 'heterotopię filologiczną' zob. np. Appadurai, 1996; Foucault, 1971; Foucault, 1984/1986; Hess, 1994). Czynić to będą w duchu zdecydowanie bardziej 'auto-konstruktywistycznym', tj. przy ewentualnej i raczej uzupełniającej obecności nauczyciela tylko jako kompetentnego doradcy i przewodnika w zupełnie nowym typie pedagogiki, 'pedagogice spotkania' (ang. pedagogy of encounter), czy wręcz 'pedagogice wirtualnej' (ang. online pedagogy), a więc z całkowitym odrzuceniem modelu dydaktyki paternalistycznej (zob. uwagi w podrozdziale II powyżej, także von Glasersfeld, 1989; Welikala, 2011) i przy rosnącej roli tzw. 'tutoringu wirtualnego' (ang. online tutoring, zob. np. Garrison et al., 2003; Salmon, 2004; Palloff i Pratt, 2007).

W konsekwencji możliwe będzie wyciąganie $\mathrm{z}$ tychże ekspozycji różnych elementów potrzebnych danemu uczestnikowi tych studiów i składanie ich w dowolne mniej lub bardziej funkcjonalne całości zgodnie z jego życzeniem. Będą to więc studia w maksymalnie otwartej i mieszanej formule 'poprzez kultury i języki' w stronę 'dowolnych' (tj. giętkich/nienormowanych) zestawów kulturowo-językowych, ang. cross-flex studies, blended studies), a więc różnie przez studentów kształtowanych i zmiennych scenariuszy w obrębie tego, co już Lave i Wenger dość dawno temu nazwały 'uczeniem się sytuacyjnym' (ang. situated learning, Lane i Wenger, 1991; zob. także Glenn i Gordon, 1999; Sole i Edmondson, 2002).

Wydaje się jednocześnie, że wszystko to odbywać się będzie w mniej społecznie kontrolowanej, bardziej konsumpcyjnie i przyjemnościowo nastawionej formule 'auto-podarunku' (ang. self-gift, zob. np. Higgins, 1997; Higgins, 2002; Mick i DeMoss, 1990; Olhavsky i Whan, 1993; Cloke i Johnston, 2005) i wspomagającym tę formułę wymiarze 'sieci edukacyjnych', pozwalających poszczególnym uczestnikom zarówno zaspokajać indywidualne aspiracje intelektualne jak i w dużej mierze samemu monitorować swoje osiągnięcia. W tym sensie można z pewnością zgodzić się z Nicholasem Carrem (2010), który w kontekście rozwijającego się dynamicznie Internetu i jego zastosowań w globalnym udostępnianiu wiedzy mówi o zdobywaniu wiedzy w wymiarze czysto prywatnym i w najwyższym stopniu indywidualnym (Carr, 2010; zob. także Terranova, 2004, w sprawie 'kultury sieci'). 
Mówiąc wprost: celem studiów o charakterze panfilologicznym będzie ogólne przygotowanie uczestników tego typu studiów do w niczym nieuprzedzonych, maksymalnie otwartych i wielokrotnie powtarzanych spotkań z etniczno-kulturową różnorodnością 'całego świata' (jako świata o zwiększonej i coraz bardziej rosnącej łączliwości/sieciowości i tym samym rosnącej gęstości, a także świata o maksymalnie zmniejszonych odległościach, zob. np. Cairncross, 2001; Jones, 2015), stanowiących naturalną i niejako wewnętrznie 'syntoniczną' (ang. syntony) 'arenę' (być może nawet pozaszkolną, zob. np. Illich, 1971) przeznaczoną do odbywania takich kulturowo-językowo-komunikacyjnych spotkań.

Tym samym studia te będą przygotowywać uczestników do nabywania szerokich podstaw, wręcz o charakterze encyklopedycznym, i upoważniać tychże uczestników do ewentualnego późniejszego nałożenia na tę uniwersalną, maksymalnie otwartą i pierwotnie przyjemnościowo-konsumpcyjną (hedoniczno-eudajmoniczną, zob. np. Sumner, 1996; Tännsjö, 1998; Veenhoven, 2003,) matrycę określonych ograniczeń zawodowych wynikających z konkretnych późniejszych zamówień społeczno-ekonomicznych (ang. long-term-on-the-job-training), niekoniecznie jednak związanych z zawodem nauczyciela języków nowożytnych nierodzimych, a bardziej jednak promujących postawę swoistego 'przewodnika' lub 'podróżnika po kulturach i językach świata' (ang. world culture-language guide/aide czy też, jakbyśmy powiedzieli 'profilera kultur', bądź 'mistrza kultury', odpowiednio ang. culture profiler, culture champion) bądź w bardziej praktycznym wymiarze 'międzynarodowego negocjatora' (ang. international negotiator, zob. np. Lewis, 2006). Śmiało można takie studia objąć bardziej ogólną altruistyczną i empatyczną zarazem zasadą: „im więcej mam, tym więcej dam innym" (zob. np. Weiner, 1992).

Studia w ewolucyjnej fazie PF można będzie też określić programowo jako studia zdecydowanie 'bez barier', czyli o charakterze wyraźnie kosmopolitycznym, tożsamościowo najszerszym, a więc o charakterze najbardziej hybrydowym i niejako 'renesansowym', a więc najbardziej otwartym, tj. transnarodowym, transetnicznym i transjęzykowym, w wymiarze globalnej synchronii i wszelakich synergii (np. technologicznych, zob. np. Vockley, 2017) w kształtującym się na naszych oczach Pax Globalica (status języka: pluriglossia, multiglossia, transsglossia) i transkulturowym wybiegu (zob. np. Hannerz, 1996; Marsh et al., 1999; Scheffler, 1999; Risager, 2007; Puppel, 2007; Chernilo, 2009; Mazon, 2009; De Florio-Hansen, 2010; Zarate et al., 2010; Rovisco i Nowicka, 2011; Delanty, 2012; Coryell et al., 2013; Twine i Gardner, 2013; Birk, 2014).

W formule tej wszystkie języki nowożytne nierodzime, duże i małe, wraz z ich kulturowymi otoczkami, mieć będą charakter wybitnie równościowy w globalnej wspólnocie kulturowo-językowo-komunikacyjnej (tj. 'ekokratyczny', czyli wedle ekologicznie umotywowanej zasady: ‘jak równy z równym', zob. Puppel, 2007). W konsekwencji umiejscowienie ich w porządku komunikacyjnym graficznym jako jedynym portalu wejściowym nie będzie już tak zasadnicze, jak to miało miejsce 
w ortodoksyjnych układach UFK, UKNR i UFNN. Słowem, równorzędnego znaczenia nabiorą wszystkie porządki komunikacyjne, wszystkie kultury lokalne i wszystkie języki w globalnym i transkulturowym spotkaniu (zob. np. Storti, 2017; Ting-Toomey, 1999; Gudykunst i Moody, 2002; Maurais i Morris, 2003; Ting-Toomey i Chung, 2012).

Taka właśnie formuła odbywania studiów filologicznych o nachyleniu kosmopolityczno-ekokratycznym, mających jednocześnie charakter 'wolnego wybiegu' w globalnej arenie kulturowo-językowo-komunikacyjnej (ang. global communication studies), jest nie tylko w pełni zrozumiała i całkowicie odmienna od tradycyjnej ortodoksji, tj. zawodowo bardzo wąskiej i programowo bardziej rygorystycznie kontrolowanej formuły studiów filologicznych odbywanych w poprzednich fazach ewolucji $\mathrm{F}$, podporządkowanych $\mathrm{w}$ pełni ściśle zawodowym profilom, ale także w pełni pożądana i bardziej satysfakcjonująca intelektualnie (poznawczo) dla ich uczestników w kontekście swoistego 'kurczenia się' naszej planety, gęstnienia przestrzeni kulturowo-językowo-komunikacyjnej i głębokiej internacjonalizacji wszelkich kontaktów międzyosobowych w warunkach gwałtownie rozwijających się technologii komunikacyjnych (zob. np. Turiman i in., 2012). Formuła ta będzie więc lepiej przylegała do przebiegających przez naszą planetę nieuniknionych procesów globalizacyjnych przede wszystkim w wymiarze koniecznej powszechnej akceptacji różnorodności kulturowo-językowej i rosnącej potrzeby intensyfikacji wszelkich pokojowych kontaktów w obrębie tejże różnorodności, a także w procesie tworzenia globalnej kulturowo-językowej kompetencji poszczególnych komunikatorów w coraz bardziej integrującym się świecie (ang. global cultural-linguistic competence for an inclusive world).

Optymalnym wynikiem edukacji w wymiarze UPF, tj. w bardziej ogólno-pragmatycznym nachyleniu, byłoby (będzie) nasycenie przestrzeni społecznej przez adeptów-specjalistów zdolnych do uznania tych studiów jako czyniących całą wspólnotę ludzką bardziej sobie przyjazną i empatyczną (zob. np. Rifkin, 2009) i w ostatecznym rozrachunku bardziej bliską osiągnięcia wymiaru powszechnego 'obywatelstwa globalnego' (ang. global citizenship, zob. np. Peters et al., 2008).

Byłoby ono właśnie wyrażane $\mathrm{m}$. in. poprzez stopniowe osiąganie powszechnego dobrostanu kulturowo-językowo-komunikacyjnego (a więc poprzez formułę 'lepszego bycia' danego komunikatora, zob. Laszlo i Laszlo, 2000; Rychen i Salganik, 2003) we wszelkich jego wymiarach, także tych ściśle zawodowych, co w perspektywie czysto filologicznej sygnalizuje udział w tym zjawisku bardziej wyspecjalizowanego i nakładanego niejako wtórnie na treści kosmopolitycznoencyklopedyczne komponentu filologicznego obejmującego podstawową dla człowieka diadę 'język - kultura'. Tym razem jednak chodziłoby o studia o globalnie i programowo otwartym (giętkim/nienormowanym) charakterze i jednocześnie we wszystkich trzech porządkach komunikacyjnych (tj. ustnym, graficznym i hybrydowym). 


\section{Podsumowanie}

Przedstawiony powyżej krótki opis ewolucji filologii nasuwa następujące podsumowanie:

- Ewolucja F przebiega(ła) od zakresów odpowiednio wąskich do zakresów coraz szerszych, czyli od UFK, poprzez UFNR i UFNN do najszerszego zakresu w UPF.

- Zakresy UFK, UFNR, UFNN stanowią przypieczętowaną długim okresem trwania i społecznej przydatności ortodoksję filologiczną.

- Zakresy UFK, UFNR, UFNN są 'jednoportalowe', tj. wejście do ich linearnej struktury prowadzi tylko od portalu odpowiednio obficie rozwiniętej wszelkiej spuścizny literackiej i pisemnej (WSLiP).

- W przypadku UFK, UFNR i UFNN jedynym i najważniejszym portalem 'wejściowym' jest WSLiP (odpowiednio: 'klasyczna' (K), 'nowożytna rodzima' (NR) i 'nowożytna nierodzima' (NN), w szczególności jej wymiar literacki).

- Portal WSLiP, który w sposób naturalny umiejscowiony jest w graficznym (pisanym i drukowanym) porządku komunikacyjnym, jest jednocześnie elementem fundamentalnym i przez to nieodzownym dla zaistnienia faz ewolucyjnych I-III w ewolucji F.

- Wejście do powyższego portalu uruchamia stałą sekwencję działań w obrębie danego UF (a więc odpowiednio UFK, UFNR, UFNN) prowadzącą do wszelkich działań w obrębie dalszych części danego układu filologicznego.

- Fazy I-III ewolucji F mają charakter bardzo silnie społecznie zredukowany (tj. społecznie zamówiony dla realizacji konkretnych celów zawodowych) i nasycają przestrzeń społeczną odpowiednio wykształconymi (poprzez nabytą wiedzę i umiejętności) i w pełni licencjonowanymi (poprzez społecznie akceptowane dyplomy) pracownikami o nachyleniu ściśle zawodowym 'niwy filologicznej' w zakresie języków najbardziej 'tęgich', jednocześnie przygotowanymi do świadczenia zróżnicowanych społecznie zamawianych usług o charakterze dydaktyczno-translatorsko-komentarzowym i tradycyjnie podlegającymi w okresie kształcenia działaniu ze strony głównie 'dydaktyki paternalistycznej'.

- Faza IV ewolucji F ma charakter zdecydowanie szerszy, tj. bardziej zróżnicowany i wieloportalowy (a więc dający możliwość wchodzenia do dowolnych części układu filologicznego), sygnalizując w najwyższym stopniu zmienność zainteresowań i motywacji uczestników studiów w zakresie PF, w tym również silniejszych motywacji o charakterze szeroko przyjemnościowym. Faza ta ma również wyraźną tendencję do bardziej giętkiego/nienormowanego i wysoce spersonalizowanego, zarazem bardziej twórczego i samo-podarunkowego nabywania szeroko rozumianej wiedzy filologicznej i kształtowania odpowia- 
dających jej zróżnicowanych i zmiennych umiejętności w zakresie wszystkich kultur lokalnych i wszystkich języków, zarówno tych istniejących tylko w porządku komunikacyjnym mówionym jak i tych, które rozwinęły porządek komunikacyjny graficzny (pisany i drukowany).

- Faza IV ewolucji F generować będzie zupełnie innego typu adeptów studiów filologicznych niż czyniły to fazy I-III. Będą oni w swoim głównie samokształceniu (tj. podaży samogenerowaniu wiedzy i umiejętności) podlegać przede wszystkim działaniu dydaktyki pozanauczycielskiej i zdecydowanie niepaternalistycznej. Inni też będą w przyszłości prowadzący PF specjaliści 'niwy panfilologicznej' w wymiarze ściśle akademickim: kosmopolityczni, nie tak wąsko językowo europo-centryczni, lecz transjęzykowi, transkulturowi i transkomunikacyjni.

- Wzrośnie także z pewnością w odpowiedzi na zdecydowanie bardziej giętki/nienormowany, samo-podarunkowy i przyjemnościowy charakter studiów w fazie PF wrażliwość i 'responsywność' jej adeptów na wszelkie dokonujące się zmiany w funkcjonowaniu świata jako całości w rozumieniu jego kulturowo-językowo-komunikacyjnych uwarunkowań, tj. w ramach globalnej wspólnoty kulturowo-językowo-komunikacyjnej.

- Całość powyższej dyskusji można ostatecznie ująć w odpowiednią 'skalę filologiczną’ będącą wyrazem synchronii pomiędzy typami (fazami ewolucji) filologii omówionymi $w$ niniejszym opracowaniu z jednej strony a stopniem dostępu do zasobów kompleksu kulturowo-językowo-komunikacyjnego (kjk) z drugiej. Wyżej wymienioną skalę filologiczną można przedstawić za pomocą następującego schematu (Rys. 6):

\section{Faza ewolucji filologii \\ Stopień dostępu do kompleksu zasobów kulturowo-językowo-komunikacyjnych (kjk)}

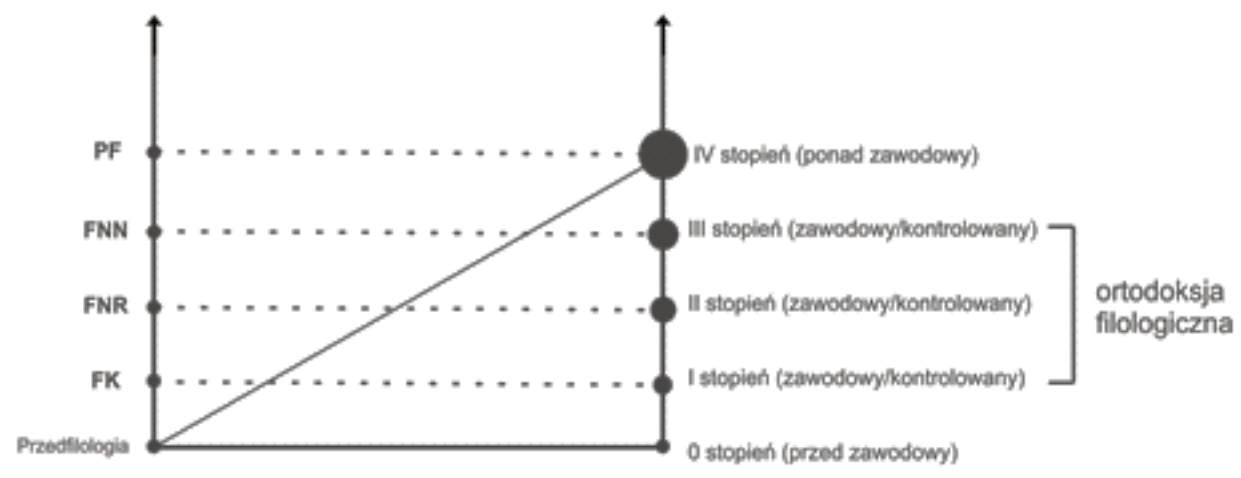

Rys. 6. Skala filologiczna 
Widać na niej powiększający się stopień dostępu komunikatorów do całego kompleksu zasobów kulturowo-językowo-komunikacyjnych (kjk) wraz z przechodzeniem filologii przez kolejne fazy jej ewolucji. Ma to bezpośredni związek ze stopniowym poszerzaniem zawodowości w ramach ortodoksji filologicznej z jednej strony jak i ostatecznie z całościowym i wieloportalowym dostępem komunikatorów do całokształtu kompleksu kjk z drugiej.

Filologio, ad multos annos (czyli ‘żyj długo i bądź zdrowa’)!

\section{Wybrana literatura}

Algeo, J. 2010. The origins and development of the English language. Boston, Mass.: Wadsworth.

Allen, W.S. 1965/1989. Vox Latina. A guide to the pronunciation of Classical Latin. Cambridge: Cambridge University Press.

Anderson Koenig, J. 2011. Assessing $21^{\text {st }}$ century skills: summary of a workshop. Washington, D.C.: The National Academies Press.

Appadurai, A. 1996. "Global ethnoscapes: notes and queries for a transnational anthropology". W zbiorze: Appadurai, A. (red.). Modernity at large: cultural dimensions of globalization. Minneapolis: University of Minnesota Press. 48-65.

Arystoteles. 2016. Corpus Aristotelicum. Vol. I: The organon Springer Verlag: Excercere Cerebrum Publications. Na podstawie opracowania: Bekker, A.I. (red.). 1831. Corpus Aristotelicum. Aristotelis opera. Berlin: Königlichen Preussischen Akademie der Wissenschaften.

Ashtadhyayi. 2018. Encyclopedia Britannica. Encyclopedia Britannica Online. https://www.britannica. com/topic/Ashtadhyayi.

Ashtadhyayi of Panini. 1896. Translated into English by Srisa Chandra Vasu. Benares: Published by Sindhu Charan Bose at the Panini Office.

Baker, M. (red.). 1997. Routledge encyclopedia of translation studies. London: Routledge.

Bańczerowski, J. 2001. "The linguistic legacy of Ludwik Zabrocki” W zbiorze: Puppel, S. (red.). The Ludwik Zabrocki Memorial Lecture. Poznań: Wydział Neofilologii UAM. 9-49.

Birk, T. 2014. "Critical cosmopolitan teaching and learning: a new answer to the global imperative". Diversity and Democracy 17.2.

Bogucki, P. (red.). 2008. Encyclopedia of society and culture in the ancient world. New York: Facts On File, Inc.

Brown, K. i S. Ogilvie. (red.). 2009. Languages of the world. Oxford: Elsevier.

Bukowski, P. i M. Heydel. (red.). 2009. Wspótczesne teorie przekładu. Antologia. Kraków: Znak.

Butler, E. 2010. The bellum grammaticale and the rise of the European literature. London: Routledge.

Byram, M. i M. Fleming. (red.). 1998. Language learning in intercultural perspective: approaches through drama and ethnography. Cambridge: Cambridge University Press.

Cairncross, F. 2001. The death of distance: how the communications revolution is changing our lives. Cambridge, Mass.: Harvard Business School Press.

Carr, N. 2010. The shallows: what the Internet is doing to our brains. New York: W.W. Norton and Company, Inc.

Celce-Murcia, M., D.M. Brinton i M.A. Snow. (red.). 2014. Teaching English as a second or foreign language. Boston, Mass.: Cengage Heinle.

Chernilo, D. 2009. "Cosmopolitanism and social theory". W zbiorze: Turner, B.S. (red.). The new Blackwell companion to social theory. Oxford: Blackwell Publishing. 533-550. 
Ching, F. 1997. A visual dictionary of architecture. New York: Van Nostrand Reinhold.

Cloke, P. i R. Johnston. (red.). 2005. Spaces of geographical thought: deconstructing human geography binarities. London: Sage Publications.

Coryell, J.E., B.J. Spencer i O. Sehin. 2013. "Cosmopolitan adult education and global citizenship: perceptions from a European itinerant graduate professional study abroad program". Adult Education Quarterly 64.2. 145-164.

Council of Europe. 2001. Common European framework of reference for languages: learning, teaching, assessment. Strasbourg: Language Policy Unit. Cambridge: Cambridge University Press.

Crawford, R. (red.). 1998. The Scottish invention of English literature. Cambridge: Cambridge University Press.

Crystal, D. 1997/2003. English as a global language. Cambridge: Cambridge University Press.

Dakowska, M. 2014. O rozwoju dydaktyki języków obcych jako dyscypliny naukowej. Warszawa: Wydawnictwa Uniwersytetu Warszawskiego.

Damen, L. 1987. Culture learning: the fifth dimension in the language classroom. Reading, Mass.: Addison-Wesley.

De Florio-Hansen, I. (red.). 2010. Towards multilingualism and the inclusion of cultural diversity. Kassel: Kassel University Press.

Delanty, G. 2012. "Introduction: the emerging field of cosmopolitan studies". W zbiorze: Delanty, G. (red.). Routledge handbook of cosmopolitanism studies. London: Routledge. 1-8.

Dinneen, F.P. 1967. An introduction to general linguistics. New York: Holt, Rinehart and Winston.

Downey, M. i A.V. Kelly. 1979. Theory and practice of education: an introduction. $2^{\text {nd }}$ ed. New York: Harper and Row.

Doyle, B. 1986. "The invention of English". W zbiorze: Colls, R. i P. Dodd. (red.). Englishness: culture and politics. 1880-1920. Beckenham: Croom Helm. 89-115.

Dworkin, G. 1988/1997. The theory and practice of autonomy. Cambridge: Cambridge University Press.

Ellis, S. 1964. "Hypercorrect dialectal pronunciation". Le Maître Phonétique. 2-3.

Engler, B. 1990. Poetry and community. Tübingen: Stauffenberg.

Europeans and their languages. 2006. European Commission (Directorate General for Education and Culture, Directorate General Press and Communication): Special Eurobarometer 243.

Finkenstaedt, T. 1983. Kleine Geschichte der Anglistik in Deutschland: eine Einführung. Darmstadt: Wissenschaftliche Buchgesellschaft.

Finkenstaedt, T. i G. Scholtes. (red.). 1983. Towards a history of English studies in Europe. Augsburg: University of Augsburg.

Fisiak, J. (red.). 1991. Further insights into contrastive analysis. Amsterdam: John Benjamins.

Foucault, M. 1970/1989/2005. The order of things: an archaeology of the human sciences. London: Tavistock/Routledge.

Foucault, M. 1984. "Des espaces autres". Architecture, Mouvement, Continuité 5. 46-49. Tłumaczenie na angielski: Jay Miskowiec 1986. "Of other spaces". Diacritics 16.1. 22-27.

Framework for 21st century learning. 2009. Tucson, AZ: The Partnership for $21^{\text {st }}$ Century Skills.

Freire, P. 1970/2005. Pedagogy of the oppressed. $30^{\text {th }}$ anniversary edition. New York: Continuum.

Frey, C.B. i M.A. Osborne. 2013. "The future of employment: how susceptible are jobs to computerization?". Available on-line.

García, O., N. Flores i M. Spotti. (red.). 2017. The Oxford handbook of language and society. Oxford: Oxford University Press.

Garrison, D.R., T. Anderson i R. Garrison. 2003. E-learning in the $21^{\text {st }}$ century: a framework for research and practice. London: Routledge.

Gimson, A.C. 1962/2001. An introduction to the pronunciation of English. London: Arnold. 
Glenn, J.C. i T.J. Gordon. 1999. The millennium project: issues and opportunities for the future. New York: North-Holland.

Goody, J. 1987. The interface between the written and the oral. Cambridge: Cambridge University Press.

Goodykunst, W.B. i B. Moody. (red.). 2002. Handbook of international and intercultural communication. Drugie wydanie. Thousand Oaks: Sage Publications.

Górecki, A. 2014. "O jezuickiej Ratio studiorum". Christianitas 58. 58-69.

Graff, G. i M. Warner. (red.). 1989. The origins of literary studies in America: a documentary anthology. London/New York: Routledge.

Grucza, F. 2006. "Glottodydaktyka: nauka - praca naukowa - wiedza". Przeglad Glottodydaktyczny 20. $5-48$.

Guzzetti, B., K. Elliott i D. Welsch. 2010. DIY media in the classroom: new literacies across content areas. New York: Teachers College Press.

Hannerz, U. 1996. Transnational connections: culture, people, places. London: Routledge.

Harklau, L. 2005. "Ethnography and ethnographic research on second language teaching and learning". W zbiorze: Hinkel, E. (red.). Handbook of research in second language teaching and learning. Mahwah, N.J.: Lawrence Erlbaum Associates. 179-194.

Harris, W. 1991. Ancient literacy. Cambridge, Mass.: Harvard University Press.

Haskins, C.H. 1923. The rise of universities. New York: Henry Holt and Company. Także najnowsze wydanie: 2017. The rise of universities: with a new introduction by L.S. Lewis. London/New York: Routledge.

Heath, S.B. i B.V. Street. 2008. On ethnography: approaches to language and literacy research. New York: Teachers College.

Hejwowski, K. 2004. Kognitywno-komunikacyjna teoria przektadu. Warszawa: Wydawnictwo Naukowe PWN.

Hess, D.J. 1994. The whole world guide to culture learning. Yarmouth, ME: Intercultural Press.

Higgins, E.T. 1997. "Beyond pleasure and pain". American Psychologist 52.12. 1280-1300.

Higgins, E.T. 2002. "How self-regulation creates distinct values: the case of promotion and prevention decision-making". Journal of Consumer Psychology 12.3. 177-191.

Hufeisen, B. i G. Neuner. (red.). 2004. The plurilingualism project: tertiary language learning - German after English. Strasbourg: Council of Europe.

Hui-chin Lin, G. i P. Shih-chieh Chien. 2010. An introduction to English teaching: a textbook for English educators. Saarbrücken: VDM Verlag Dr. Muller.

Human development report 2010. The real wealth of nations: pathways to human development. New York: Published for the United Nations Development Programme (UNDP).

Illich, I. 1971. Deschooling society. London: Calder and Boyars.

Jassem, W. 1962/2011. Podręcznik wymowy angielskiej. Warszawa: PWN.

John of Salisbury. 2009. The metalogicon. A twelfth-century defense of the verbal and logical arts of the Trivium. Przekład na język angielski D.D. McGerry. Philadelphia: Paul Dry Books, Inc.

Johnston, D.M. 2008. The historical foundations of world order: the tower and the arena. Leiden: Martinus Nijhoff Publishers.

Jones, C. 2015. Networked learning: an educational paradigm for the age of digital networks. Cham, Switzerland: Springer International.

Jones, D., P. Roach, J. Setter i J. Esling. (red.). 2011. Cambridge English pronouncing dictionary. $18^{\text {th }}$ ed. Cambridge: Cambridge University Press.

Kapr, A. i D. Martin. 1996. Johann Gutenberg: the man and his invention. Aldershot, UK: Scolar Press.

Karoly, L.A. 2004. The 21st century at work: forces shaping the future workforce and workplace in the United States. Santa Monica, CA: RAND Corporation. 
Kautz, T., J.J. Heckman, R. Diris, B. ter Weel and L. Borghans. 2014. "Fostering and measuring skills: improving cognitive and non-cognitive skills to promote lifetime success". Cambridge, Mass.: National Bureau of Economic Research (NBER) Paper Series. Working Paper 20749.

Klemensiewicz, Z. 1974. Historia języka polskiego. Warszawa: PWN.

Komorowska, H. 2013. Metodyka nauczania języków obcych. Warszawa: Wydawnictwo Fraszka Edukacyjna.

Kottak, C.P., J.J. White, R.H. Furlow i P.C. Rice. (red.). 1997. The teaching of anthropology: problems, issues, and decisions. Mountain View, CA: Mayfield Publishing.

Kramsch, C. 1993. Context and culture in language teaching. Oxford: Oxford University Press.

Krysztofiak, M. 2011. Translatologiczna teoria i pragmatyka przekladu artystycznego. Poznań: Wydawnictwo Naukowe UAM.

Krysztofiak, M. 2013. Einführung in die Übersetzungkultur. Frankfurt am Main: Peter Lang.

Lamb, S., Q. Maire i E. Doecke. 2017. Key skills for the 21 st century: an evidence-based review. Melbourne, Australia: Victoria University (Centre for International Research on Education Systems).

Lane, J. i E. Wenger. 1991. Situated learning: legitimate peripheral participation. Cambridge: Cambridge University Press.

Laszlo, K.C. i A. Laszlo. 2000. "Learning to become: creating evolutionary learning community through evolutionary systems design". W zbiorze: Miller, R. (red.). Creating learning communities. New York: Solomon Press. 231-240.

Levine, J.M. 1991. The battle of the books: history and literature in the Augustan age. Ithaca: Cornell University Press.

Levinson, D. 1991-1996. Encyclopedia of world cultures. Boston, Mass.: G.K. Hall. 10 vols.

Lewicki, R. 2017. Zagadnienia lingwistyki przekładu. Lublin: Wydawnictwo UMCS.

Lewis, R.D. 2006. When cultures collide: leading across cultures. $3^{\text {rd }}$ ed. Boston: Nicholas Brealey International.

Lowndes, S. 2016. The DIY movement in art, music and publishing: subjugated knowledges. London: Routledge.

Making European area of lifelong learning a reality. European Commission. Luxembourg: Office for Official Publications of the European Communities. COM(2001) 678 final.

Małunowicz, L. 1960. Wstęp do filologii klasycznej wraz z metodologia pracy umystowej. Lublin: Towarzystwo Naukowe Katolickiego Uniwersytetu Lubelskiego (TNKUL).

Marsh, D., C. Enner i D. Sygmund. 1999. Pursuing plurilingualism. Jyväskylä: University of Jyväskylä.

Marton, W. 1972. Nowe horyzonty nauczania języków obcych. Warszawa: PZWSz.

Maurais, J. i M.A. Morris. (red.). 2003. Languages in a globalising world. Cambridge: Cambridge University Press.

Mazon, B.K. 2009. "Creating the cosmopolitan US undergraduate: study abroad and an emergent global student profile". Research in Comparative and International Education 4.2. 141-150.

McLeod, B. 1976. "The relevance of anthropology to language teaching". TESOL Quarterly 10.2. 211-220.

McMurty, J. 1985. English language, English literature: the creation of an academic discipline. London: Mansell.

Mejor, M. 2000. Sanskryt. Warszawa: "Dialog".

Mick, D.G. i M. DeMoss. 1990. "To me from me: a descriptive phenomenology of self-gifts". Advances in Consumer Research 17. 677-682.

Murphy, J.J. 1974. Rhetoric in the Middle Ages: a history of rhetorical theory from Saint Augustine to the Renaissance. Berkeley, CA: University of California Press..

Murphy, J.J. 1989. Medieval rhetoric: a select bibliography. Toronto: University of Toronto Press. 
Olhavsky, R.W. i D.L. Whan. 1993. "Self-gifts: a metacognition perspective". Advances in Consumer Research 20. 547-552.

Ong, W.J. 1982/2002. Orality and literacy: the technologizing of the word. London: Routledge.

Palloff, R.M. i K. Pratt. 2007. Building online communities: effective strategies for the virtual classroom. $2^{\text {nd }}$ ed. New York: John Wiley and Sons/Jossey-Bass.

Peile, J. 1877. Philology. London: Macmillan and Co.

Peters, M.A., A. Britton i H. Blee. (red.). 2008. Global citizenship education: philosophy, theory and pedagogy. Rotterdam: Sense Publishers.

Peterson, P., Tierney, R., Baker, E. i B. McGaw. (red). 2010/2018. International encyclopedia of education. 3rd ed. New York: Elsevier Science.

Pisarska, A. i T. Tomaszkiewicz. 1996. Wspótczesne tendencje przekładoznawcze. Podręcznik dla studentów neofilologii. Poznań: Wydawnictwo Naukowe UAM.

Polska - Europa Wschodnia: wzajemne wplywy i relacje historyczno-kulturowe, literackie i językowe. Olsztyn: Wydawnictwo Uniwersytetu Warmińsko-Mazurskiego w Olsztynie.

Puppel. S. i J. Puppel. 2005. "Zagadnienie percepcji języka naturalnego w triadzie: język ojczysty-język globalny-język sąsiedni na przykładzie triady: język polski-język angielski-język niemiecki w ujęciu ekolingwistycznym: próba typologii”. Scripta Neophilologica Posnaniensia VII. 55-95.

Puppel, S. 2000. "Jaka jesteś polska neofilologio obca A.D. 2000 i dokąd zmierzasz?”. Scripta Neophilologica Posnaniensia II. 275-291.

Puppel, S. 2007. "Interlingwalizm czy translingwalizm? Interkomunikacja czy transkomunikacja? Uwagi w kontekście współistnienia języków naturalnych w ramach globalnej wspólnoty kulturowojęzykowo-komunikacyjnej”. W zbiorze: Puppel, S. (red.). Spoteczeństwo-kultura-język. W stronę interakcyjnej architektury komunikacji. Scripta de Communicatione Posnaniensi Tom I. Poznań: Katedra Ekokomunikacji UAM. Druk: Zakład Graficzny UAM. 79-94.

Puppel, S. 2012. "Kultura nauczycielska' a 'kultura pozanauczycielska': uwagi w sprawie apostazji, herezji i schizmy wobec dalszego istnienia ortodoksji nauczycielskiej w XXI wieku". W zbiorze: Grzywka, K. et al. (red). Kultura - literatura - język. Pogranicza komparatystyki. Prace ofiarowane Profesorowi Lechowi Kolago w 70. rocznicę urodzin. Warszawa: Instytut Germanistyki Uniwersytetu Warszawskiego. 1535-1545.

Puppel, S. (red.). 2015. MOTEK. Motywy ekolingwistyczne: w stronę ekoglottodydaktyki. Scripta de Communicatione Posnaniensi Tom VII. Poznań: Katedra Ekokomunikacji UAM. Druk: Zakład Graficzny UAM.

Puppel, S. 2017. ECOLI[S]²: essays and notes on ecolinguistic synergy and synthesis. Scripta de Communicatione Posnaniensi Tom VIII. Poznań: Katedra Ekokomunikacji UAM. Druk: Zakład Graficzny UAM.

Puppel, S. 2018. "Communicology from the 'portals' perspective: a summative-schematic view". Scripta Neophilologica Posnaniensia XVIII. 83-88.

Rifkin, J. 2009. The empathic civilization: the race to global consciousness in a world in crisis. New York: J.P. Tarcher/Penguin.

Risager, K. 2007. Language and culture pedagogy: from a national to a transnational paradigm. Clevedon, UK: Multilingual Matters.

Roberts, C., M. Byram, A. Barro, S. Jordan i B. Street. 2001. Language learners as ethnographers. Clevedon, UK: Multilingual Matters.

Rospond, S. 2005. Gramatyka historyczna języka polskiego. Warszawa: Wydawnictwo Naukowe PWN.

Rovisco, M. i M. Nowicka. (red.). 2011. The Ashgate research companion to cosmopolitanism. London: Routledge.

Rychen, D.S. i L.H. Salganik. 2003. Key competencies for a successful life and a well-functioning society. Göttingen: Hogrefe and Huber. 
Salmon, G. 2004. E-moderating: the key to teaching and learning online. London: Routledge Falmer.

Sancho-Gil, J.M. i P.J. Rivera-Vargas. 2016. "The socio-economic evaluation of a European Project: The DIYLab case". Informatics 3.13. doi: 10.3390/informatics3030013.

Saville-Troike, M. 1989/2003. The ethnography of communication: an introduction. Oxford: Blackwell. Scheffler, S. 1999. "Conceptions of cosmopolitanism". Utilitas 255-276.

Schütze, H.G. i M. Slowley. (red.). 2012. Global perspectives on higher education and lifelong learners. London/New York: Routledge.

Scott, V.M. i J.A. Huntington. 2000. "Reading culture: using literature to develop C2 competence". Foreign Language Annals 35.6. 622-631.

Silva, E. 2008. Measuring skills for the $21^{\text {st }}$ century. Washington, D.C.: Education Sector Reports.

Simons, G.F. i C.D. Fennig. (red.). 2018. Ethnologue: languages of the world. 21st ed. Dallas, TX: SIL International.

Skowronek, B. 2009. "Nauczanie języków obcych: tradycja a współczesność, instrukcja a konstrukcja". Lingwistyka Stosowana 1. 227-235.

Skowronek, B. 2015. "Glottodydaktyka od profesora Ludwika Zabrockiego po dzień dzisiejszy". W zbiorze: Puppel, S. (red.). MOTEK. Motywy ekolingwistyczne: w strone ekoglottodydaktyki. 151-164.

Sole, D. i A. Edmondson. 2002. "Situated knowledge and learning in dispersed teams". British Journal of Management 13.S2. 17-34.

Spencer, A. 2005. DIY: the rise of lo-fi culture. London: Marion Boyars.

Storti, C. 1994/2017. Cross-cultural dialogues: 74 brief encounters with cultural difference. Boston, Mass.: Intercultural Press.

Sullivan, S.E. 2001. "Careers in the $21^{\text {st }}$ century". Group \& Organization Management 26.3. 252-254.

Sumner, L.W. 1996. Welfare, happiness, and ethics. Oxford: Clarendon Press.

Szolginia, W. 1992. Architektura. Warszawa: Sigma NOT.

Tännsjö, T. 1998. Hedonistic utilitarianism. Edinburgh: Edinburgh University Press.

Terranova, T. 2004. Network culture: politics for the information age. London: Pluto Press.

The future of jobs: employment, skills and workforce strategy for the fourth industrial revolution. Global Challenge Insight Report. 2016. World Economic Forum.

Ting-Toomey, S. 1999. Communicating across cultures. New York: Guilford Press.

Ting-Toomey, S. i L.C. Chung. 2007/2012. Understanding intercultural communication. Oxford/New York: Oxford University Press.

Tomlinson, J. 1999. Globalization and culture. Cambridge: Polity Press.

Turiman, P., Omar, J., Daud, A.M. i K. Osman. 2012. "Fostering $21^{\text {st }}$ century skills through scientific literacy and science process skills". Procedia - Social and Behavioral Sciences 59. 110-119.

Twine, F.W. i B. Gardner. 2013. Geographies of privilege. London/New York: Routledge.

Varro, Marcus Terentius. De lingua Latina libri XXV (On the Latin language in 25 books).

Veenhoven, R. 2003. "Hedonism and happiness". Journal of Happiness Studies 4. 437-457.

Vockley, M. 2007. Maximizing the impact. The pivotal role of technology in a $21^{\text {st }}$ century education system. Partnership for $21^{\text {st }}$ Century Skills. von Glasersfeld, E. 1989/1994. "Constructivism in education". W zbiorze: Husen, T. i T.N. Postlethwaite. (red.). The international encyclopedia of education, Supplement. Vol. 1. Oxford/New York: Pergamon Press. 162-163.

Weiner, A.B. 1992. Inalienable possessions: the paradox of keeping-while-giving. Berkeley, CA: University of California Press.

Welikala, T. 2011. "Rethinking international higher education curriculum: mapping the research landscape". A position paper commissioned and published by Universitas 21, leading global network of research universities for the $21^{\text {st }}$ century. Nottingham, UK: Nottingham University, School of Education. 
Wells, J.C. 1982. Accents of English. 3 vols. Cambridge: Cambridge University Press.

Wilson, A.L. i E.R. Hayes. (red.). 2000. Handbook of adult and continuing education. San Francisco, CA: Jossey-Bass.

Winniczuk, L. 1986. Stownik kultury antycznej. Warszawa: Wiedza Powszechna.

Wiśniewska, K. 2018. The role of English as a mediating and target language in intercultural and interethnic contacts. Scripta de Communicatione Posnaniensi Tom IX. Poznań: Katedra Ekokomunikacji UAM. Druk: Zakład Graficzny UAM.

Wobalis, M. 2017. Nowe media i technologie cyfrowe w kształceniu polonistów. Poznań: Wydawnictwo Naukowe UAM.

Wright, S. 2004. Language policy and language planning: from nationalism to globalization. New York: Palgrave.

Zabrocki, L. 1975. "Zur Theorie der konfrontativen Sprachwissenschaft". Glottodidactica VII. 3-9.

Zarate, G., D. Lévy i C. Kramsch. (red.). 2010. Handbook of multilingualism and multiculturalism. Paris: Éditions des Archives Contemporaines.

Zybert, J. 2006. Issues in foreign language learning and teaching. Warszawa: Wydawnictwa Uniwersytetu Warszawskiego.

Alfabetyczny słownik skrótów użytych w pracy:

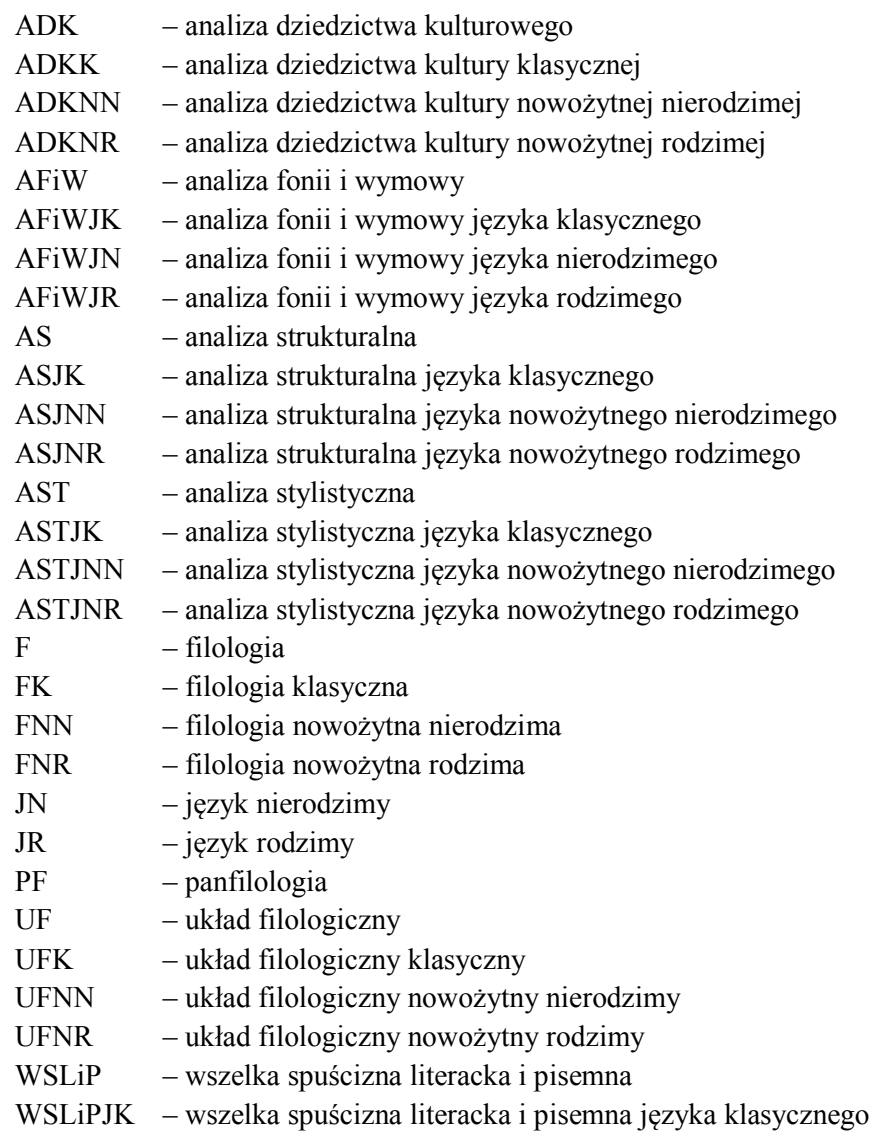


WSLiPJNN - wszelka spuścizna literacka i pisemna języka nowożytnego nierodzimego

WSLiPJNR - wszelka spuścizna literacka i pisemna języka nowożytnego rodzimego

WZP - wszelkie zastosowania praktyczne

WZPJK - wszelkie zastosowania praktyczne języka klasycznego

WZPJNN - wszelkie zastosowania praktyczne języka nowożytnego nierodzimego

WZPJNR - wszelkie zastosowania praktyczne języka nowożytnego rodzimego 